\title{
INCREASED SENSITIVITY OF ADENYLATE CYCLASE ACTIVITY IN THE STRIATUM OF THE RAT TO CALMODULIN AND GppNHp AFTER CHRONIC TREATMENT WITH HALOPERIDOL*
}

\author{
G. J. Treisman, N. Muirhead and M. E. Gnegy ${ }^{\dagger}$ \\ Department of Pharmacology, M6322 Medical Science I, University of Michigan, Ann Arbor, \\ MI 48109, U.S.A.
}

\author{
(Accepted 9 September 1985)
}

\begin{abstract}
Summary-Chronic treatment of rats with haloperidol causes behavioral supersensitivity to dopaminergic agonists and an increase in the sensitivity of adenylate cyclase activity in the striatum to stimulation by dopamine. In this study the authors examined whether chronic treatment with haloperidol could elicit a change in sensitivity of adenylate cyclase in the striatum of the rat for guanyl nucleotides and the endogenous $\mathrm{Ca}^{2+}$-binding protein, calmodulin. These agents increase the activation of adenylate cyclase activity by dopamine but act beyond the level of the dopamine receptor. Male, Sprague-Dawley rats were injected subcutaneously with either $0.6 \mathrm{mg} / \mathrm{kg}$ haloperidol or vehicle for 14 days. Four days after the last injection, the animals were sacrificed and the activity of adenylate cyclase was measured in a EGTAwashed particulate preparation of the striatum. There was an increase in the activation of adenylate cyclase activity by calmodulin and GppNHp but not by guanosine triphosphate (GTP) in particulate fractions of the striatum from rats treated with haloperidol as compared to controls. The sensitivity of adenylate cyclase to calmodulin was increased 5-fold in particulate fractions from rats treated with haloperidol as opposed to vehicle-treated rats. The lack of change in activation by GTP was not due to an altered activity of GTPase in rats treated with haloperidol. In animals treated for 14 days but not withdrawn from haloperidol there was no statistically significant increase in the sensitivity of adenylate cyclase to calmodulin. There was no change in activation of the enzyme by GppNHp or GTP as compared to control. The activation of adenylate cyclase by calmodulin was not affected when haloperidol was added in vitro to the assay or after the acute injection of rats with haloperidol.

These results demonstrate that the development of dopaminergic supersensitivity after withdrawal from chronic blockade of dopamine receptors resulted in increased sensitivity of post-receptor coupling mechanisms, as well as in changes in the receptor-mediated activity. In previous studies, increases in DA-stimulated adenylate cyclase activity were found with this treatment regimen. In this study it was shown that although basal activity was not changed, there was a selective increase in the sensitivity of adenylate cyclase to stimulation by calmodulin and GppNHp after chronic receptor blockade. These findings support previous observations suggesting a regulatory role for calmodulin in dopaminestimulated adenylate cyclase activity.
\end{abstract}

Key words: supersensitivity, adenylate cyclase, dopamine, calmodulin, haloperidol.

The purpose of this study was to investigate further the role of calmodulin $(\mathrm{CaM})$ in the regulation of dopamine (DA)-stimulated adenylate cyclase activity. Adenylate cyclase in the brain is activated by calmodulin, a low-molecular weight calcium-binding protein (Brostrom, Brostrom and Wolff, 1978; Cheung Bradham, Lynch, Lin and Tallant, 1975). Several lines of evidence suggest a role for calmodulin in modulating dopaminergic activity (Gnegy, Lau and Treisman, 1980). Striatal membranes from rats exhibiting behavioral supersensitivity to DA after

*This work was supported by a grant MH36044 from the National Institutes of Mental Health, the American Parkinson's Disease Association and the Michigan Memorial Phoenix Project.

†To whom reprints and requests should be addressed. withdrawal from chronic treatment with haloperidol had an increased content of calmodulin and increased activity of DA-sensitive adenylate cyclase (Gnegy, Lucchelli and Costa, 1977a; Gnegy, Uzunov and Costa, 1977b). Hanbauer, Pradham and Yang (1980) reported that membranes prepared from slices of striatum, treated with amphetamine contained decreased activity of DA-sensitive adenylate cyclase and decreased content of calmodulin as compared to controls. Calmodulin activates basal activity of adenylate cyclase in striatal membranes from the rat and increases the sensitivity of the enzyme for DA 3-4-fold (Gnegy and Treisman, 1981). Several investigators have found two components of the activity of adenylate cyclase in the brain of the rat, including the striatum, one of which is sensitive to stimulation by calmodulin and one of which is insensitive to calmodulin (Brostrom, Brostrom and Wolff, 
1977; Heideman, Wierman and Storm, 1982; Treisman, Bagley and Gnegy, 1983). Previous studies suggested that calmodulin-sensitive adenylate cyclase activity in the striatum of the rat was activated by guanyl nucleotides, preferentially by small concentrations of the non-hydrolyzable analog, guanosine triphosphate (GTP), guanosine-5'-( $\beta, \gamma$-imido)triphosphate (GppNHp; Treisman et al., 1983).

Chronic treatment of rats with a DA antagonist such as haloperidol has been used as a model for Parkinson's disease (Hornykiewicz, 1973, 1975). After withdrawal from chronic treatment with haloperidol, rats exhibit an increased behavioral sensitivity to DA agonists (Christensen, Fjalland and Møller Nielsen, 1976; Klawans and Rubovits, 1972; Sayers, Bürki, Ruch and Asper, 1975; Tarsy and Baldessarini, 1974). In striatal membranes from rats treated chronically with haloperidol, increases in the binding of $\left[{ }^{3} \mathrm{H}\right]$ haloperidol, a measure of binding to DA D-2 receptors (Burt, Creese and Snyder, 1977) and the activity of DA-stimulated adenylate cyclase, a measure of the activity of DA D-1 receptors (Marshall and Mishra, 1980; Gnegy et al., 1977a, b; Iwatsubo and Clouet, 1975) have been reported. These changes reflect a change in dopaminergic activity at the level of the receptor.

In this study, the authors wished to determine whether the supersensitivity could be expressed through agents which affect dopaminergic stimulation, yet activate adenylate cyclase at a level beyond the receptor. The effect of chronic treatment with haloperidol on the activation of adenylate cyclase by calmodulin, as well as by GTP and GppNHp, which activate adenylate cyclase by binding to an activating guanyl nucleotide-binding protein termed $\mathbf{N}_{\mathrm{s}}$ (Rodbell, 1980; Limbird, 1981) was examined. It was found that the activity of adenylate cyclase had an increased sensitivity to both calmodulin and GppNHp but no change in sensitivity to GTP as compared to vehicle-treated controls. The lack of change in stimulation by GTP was not due to an increase in hydrolysis of GTP elicited by the treatment with haloperidol. These results demonstrate that chronic treatment with haloperidol can increase the sensitivity of adenylate cyclase to factors which affect the coupling of the DA receptor to the catalytic subunit.

\section{METHODS}

\section{Drug treatments}

Male, Sprague-Dawley rats Strain Crl: CD(SD)BR $(200-250 \mathrm{~g})$ were obtained from Charles River Breeding Laboratories, Wilmington, Massachusetts, U.S.A. The rats were injected for 14 days with $0.6 \mathrm{mg} / \mathrm{kg}$ (s.c.) of haloperidol or $0.1 \mathrm{ml} / 0.1 \mathrm{~kg}$ of a vehicle consisting of $0.9 \%$ saline solution containing $5 \mu \mathrm{l} / \mathrm{ml}$ of ethanol and $5 \mu 1 / \mathrm{ml}$ glacial acetic acid. A similar regimen has been shown to result in increased stereotyped behavior in rats after a challenge with apomorphine (Gnegy et al., 1977a). In some experiments, rats were withdrawn from the drug for 4 days before sacrifice. Rats not withdrawn from the drug were killed $1 \mathrm{hr}$ after the last injection. Acute treatments consisted of a single injection of the above solutions $1.5 \mathrm{hr}$ prior to decapitation.

\section{Preparation of particulate fraction}

Particulate fractions of striatum were prepared as described by Brostrom et al. (1978). Briefly, rats were killed by decapitation, the striata were removed and homogenized in $9 \mathrm{vol}$ of $10 \mathrm{mM}$ Tris maleate buffer, $\mathrm{pH} 7.5$ containing $1 \mathrm{mM} \mathrm{mgSO}{ }_{4}$ and $1.2 \mathrm{mM}$ ethylene glycol bis ( $\beta$-aminoethyl ether)- $N, N, N^{\prime}, N^{\prime}$ tetraacetic acid (EGTA). The homogenate fraction was centrifuged at $27,000 \mathrm{~g}$ for $20 \mathrm{~min}$ and the resulting pellet was resuspended in $9 \mathrm{vol}$ of the above buffer and centrifuged a second time. The pellet resulting from the final centrifugation was resuspended in the above buffer to a concentration of approx. $5 \mathrm{mg}$ of protein $/ \mathrm{ml}$. Protein content was determined by the method of Lowry, Rosebrough, Farr and Randall (1951).

\section{Assay of adenylate cyclase}

The activity of adenylate cyclase was measured in an assay ( $200 \mu \mathrm{l}$ volume) containing: $80 \mathrm{mM}$ Tris maleate buffer, $\mathrm{pH} 7.5,5 \mathrm{mM} \mathrm{MgSO}{ }_{4}, 2 \mathrm{mM}$ cAMP, $4 \mathrm{mM}$ phosphoenolpyruvate, $20 \mu \mathrm{g}$ pyruvate kinase, $0.12 \mathrm{mM}$ isobutylmethylxanthine, $100-150 \mu \mathrm{g}$ of particulate membrane protein, $0.15 \mathrm{mM}$ EGTA and $1 \mathrm{mM}\left[\alpha{ }_{-}^{32} \mathrm{P}\right] \mathrm{ATP}$ ( $1 \mu \mathrm{Ci}$ per assay) with or without additions such as GppNHp, GTP, $\mathrm{CaCl}_{2}$ and calmodulin. Assays were incubated for $10 \mathrm{~min}$ and the reaction was stopped by heating for $1 \mathrm{~min}$ at $95^{\circ} \mathrm{C}$. A solution $(200 \mu \mathrm{l})$ containing $20 \mathrm{mM}$ ATP and $0.7 \mathrm{mM}$ cAMP was then added to the tubes. The particulate material was centrifuged and ${ }^{32} \mathrm{P}-$-labelled cAMP in the supernatant fraction was determined by the method of Krishna, Weiss and Brodie (1968). Recovery of the cAMP was measured using the $\left[{ }^{3} \mathrm{H}\right]$ cAMP and was usually $80-90 \%$. Free or effective concentrations of $\mathrm{Ca}^{2+}$ were calculated using a dissociation constant for $\mathrm{Ca}^{2+}$ EGTA of $4.08 \times 10^{-8} \mathrm{M}$ according to the method of Nanninga and Kempen (1971).

\section{Assay of GTPase}

The activity of GTPase was assayed using [ $\left.\gamma{ }^{32} \mathrm{P}\right] G T P$ according to the method of Cassel, Levkovitz and Selinger (1977). Assay contents, modified to be more similar to those of the adenylate cyclase assay in a volume of $100 \mu \mathrm{l}$, were: $12.5 \mathrm{mM}$ Tris $\mathrm{HCl}$ buffer, $\mathrm{pH} 7.5,5 \mathrm{mM} \mathrm{MgCl}_{2}$, $1 \mathrm{mM}$ ATP, $1 \mathrm{mM}$ adenosine- $5^{\prime}$ - $(\beta, \gamma$-imido)triphosphate (AppNHp), $1 \mathrm{~mm}$ creatine phosphate, $5 \mathrm{U}$ creatine phosphokinase, $1 \mathrm{mM}$ ouabain, $2 \mathrm{mM}$ dithiothreitol, $5 \mu \mathrm{g}$ membrane protein, $150 \mu \mathrm{M}$ and $50,000 \mathrm{cpm}$ of $\left[\gamma-{ }^{32} \mathrm{P}\right] \mathrm{GTP}$ plus various additions such as nonradioactive GTP, $\mathrm{Ca}^{2+}$ and $\mathrm{CaM}$. Incubations were conducted for $10 \mathrm{~min}$ at $37^{\circ} \mathrm{C}$. Assays were 


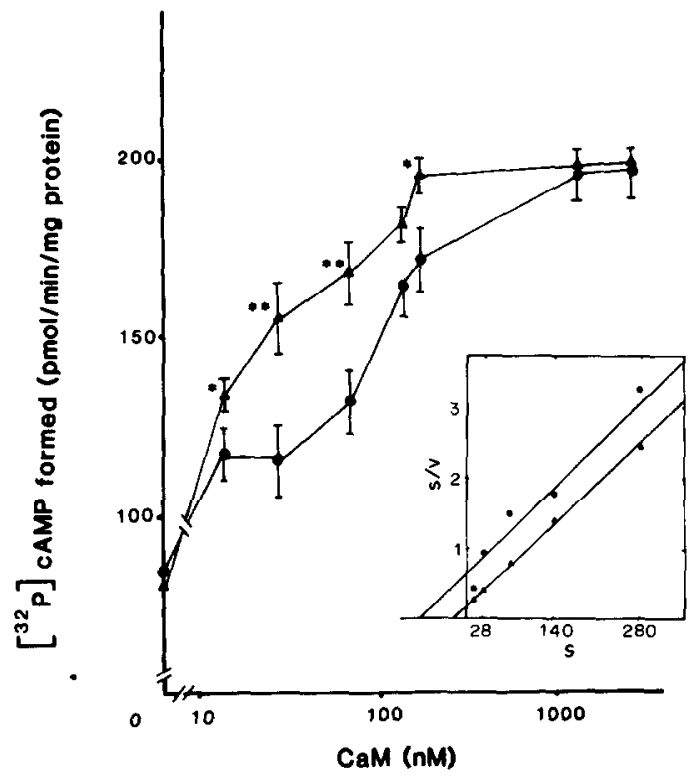

Fig. 1. Activation of the activity of adenylate cyclase by calmodulin $(\mathrm{CaM})$ in particulate fractions from the striatum of rats chronically treated with haloperidol $(\boldsymbol{\Delta})$ or vehicle (O) and withdrawn for 4 days. Activity of adenylate cyclase was measured in EGTA-washed striatal particulate fractions as described in Methods. Assays contained $0.12 \mu \mathrm{M}$ free $\mathrm{Ca}^{2+}\left(100 \mu \mathrm{M}\right.$ added $\left.\mathrm{CaCl}_{2}\right)$. Each point represents the average value from five different animals \pm SEM. ${ }^{*} P \leq 0.05 ;{ }^{* *} P \leq 0.02$. Inset: Results expressed as a Hanes plot with substrate (s) on the abscissa and substrate/velocity $(s / v)$ on the ordinate. Kinetic constants from this form of analysis are shown in Table 1.

terminated and free ${ }^{32} \mathrm{Pi}$ determined as described by Cassel et al. (1977). The activity of the low $K_{m}$ GTPase can be closely approximated by correcting for the hydrolysis of GTP by a high $\mathrm{K}_{m}$ activity of nucleoside triphosphate (Cassel et al., 1977). In the present experiments, low $K_{m}$ activity of GTPase was calculated as the difference between the number of counts per minute of ${ }^{32} \mathrm{Pi}$ released in the absence and presence of $100 \mu \mathrm{M}$ GTP.

\section{Preparation and measurement of calmodulin}

Calmodulin was purified from bovine brain using phenylscpharose chromatography and DEAEcellulose chromatography by a modification of the methods of Dedman, Potter and Means (1977) and of Gopalkrishna and Anderson (1982). The calmodulin demonstrated a single band on disc gel electrophoresis containing $10 \%$ polyacrylamide. Calmodulin was prepared in the presence of millimolar concentrations of EGTA, dialyzed against $0.05 \mathrm{M}$ $\left(\mathrm{NH}_{4}\right) \mathrm{HCO}_{3}$ and lyophilized. The calmodulin was redissolved in $10 \mathrm{mM}$ Tris maleate buffer, $\mathrm{pH} 7.5$. The $M_{\mathrm{r}}$ determined by slab gel electrophoresis using standards of known molecular weight was 16,200 daltons. Calmodulin was measured by its ability to activate calmodulin-depleted preparations of bovine brain $3^{\prime} 5^{\prime}$-cyclic-AMP phosphodiesterase
(PDE) using purified calmodulin as a standard (Gnegy, Nathanson and Uzunov, 1977c). Calmodulin-activated PDE was prepared as described by Klee and Krinks (1978).

\section{Statistics}

Statistical differences were analyzed using an unpaired Student's $t$-test.

\section{Materials}

Haloperidol was a generous gift from McNeil Laboratories, Inc. (Fort Washington, Pennsylvania, U.S.A.); $\left[\alpha-{ }^{32} \mathrm{P}\right]$ ATP (sp. act. $\quad 10-30 \mathrm{Ci} / \mathrm{mmol}$ ), [ $\gamma-{ }^{32}$ P]GTP (sp. act. $20-40 \mathrm{Ci} / \mathrm{mmol}$ ) and $\left[{ }^{3} \mathrm{H}\right] \mathrm{cAMP}$ (sp. act. $20-30 \mathrm{Ci} / \mathrm{mmol}$ ) were purchased from Amersham Searle. Phosphoenolypyruvate, AppNHp, AMP and ATP were obtained from Sigma Chemical Co.; pyruvate kinase was from Boehringer Mannheim. Both GTP and GppNHp (high pressure liquid chromatography purified) were purchased from International Chemical and Nuclear Corp. All other materials and reagents were the highest commercially available grade produced.

\section{RESULTS}

Activation of the activity of adenylate cyclase by calmodulin in particulate fractions of the striatum from rats withdrawn from chronic treatment with vehicle or haloperidol

Activation of the activity of adenylate cyclase by various concentrations of calmodulin was measured in particulate fractions of the striatum from rats treated with haloperidol or vehicle. As shown on the ordinate of Fig. 1, basal activity of adenylate cyclase did not significantly differ in the two groups. Calmodulin stimulated formation of cAMP to a greater extent in particulate fractions from animals treated with haloperidol than from controls at concentrations up to $250 \mathrm{nM}$ (Fig. 1). The activation of adenylate cyclase by calmodulin, however, did not differ significantly between the two groups at concentrations greater than $1 \mu \mathrm{M}$ calmodulin. The activity of adenylate cyclase from rats treated with haloperidol, however, had a greater sensitivity to calmodulin than did that from vehicle-treated rats. Kinetic analysis of the data using a Hanes plot (insert Fig. 1) revealed a 4.7-fold increase in sensitivity of adenylate cyclase for calmodulin in membranes from rats treated with haloperidol as compared to vehicle with no change in maximum response. The apparent kinetic constants determined using Hanes analysis for the two groups are given in Table 1 . The apparent $\mathrm{K}_{\mathrm{a}}$ for calmodulin was significantly decreased almost 5 -fold from $76 \mathrm{nM}$ in fractions from vehicle-treated rats to $16 \mathrm{nM}$ in fractions from rats treated with haloperidol. The apparent $V_{\max }$ did not change as a result of treatment with drug and was 116 and $115 \mathrm{pmol} / \mathrm{min}$ per $\mathrm{mg}$ protein in fractions from vehicle and haloperidol-treated rats, respectively. 
Table 1. Apparen kinetic constants for activation of adenylate cyclase by calmodulin (CaM) in rats treated chronically with haloperidol or vehicle

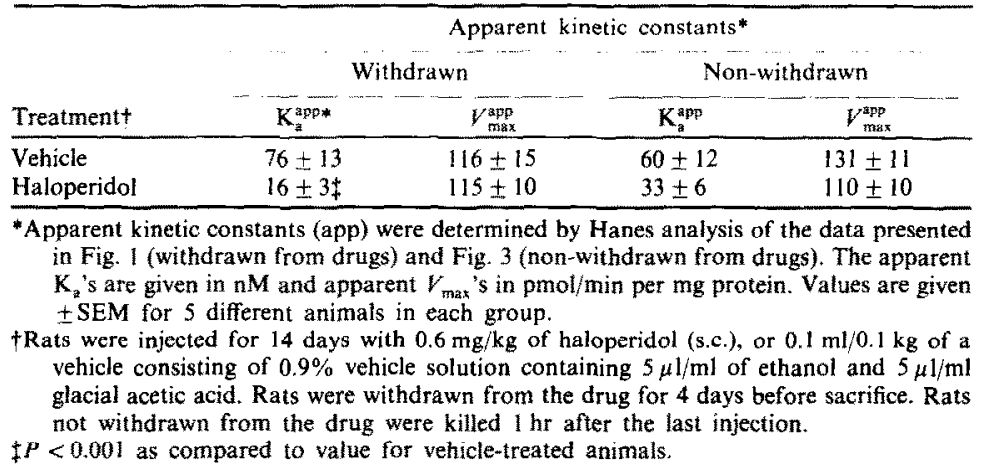

The change in sensitivity to calmodulin was not due to a difference in endogenous content of calmodulin in the particulate fractions of striatum from rats treated with haloperidol or vehicle. The calmodulin content in the EGTA-washed particulate fractions of striatum from rats treated with vehicle and haloperidol was $2.5 \pm 0.4$ and $2.5 \pm 0.3 \mathrm{ng} \mathrm{CaM} / \mu \mathrm{g}$ membrane protein, respectively; EGTA reduced the concentration of calmodulin in striatal membranes by over $50 \%$ but did not remove all of the endogenous calmodulin.

Activation of adenylate cyclase by GppNHp and GTP in particulate fractions of striatum from rats withdrawn from chronic treatment with vehicle or haloperidol

The stimulation of the activity of adenylate cyclase from the striatum by GTP and the non-hydrolyzable analog of GTP, GppNHp was examined. As shown in Fig. 2, the activity of adenylate cyclase in striatal membranes from rats treated chronically with haloperidol was significantly more sensitive to stimulation by GppNHp than that from controls. Maximal stimulation by the nucleotide occurred at $100 \mu \mathrm{M}$ GppNHp and was not different in fractions from animals treated with vehicle or haloperidol. The $\mathrm{EC}_{50}$ for $\mathrm{GppNHp}$, the effective concentration which provided $50 \%$ of the maximal activation, was $0.5 \mu \mathrm{M}$ in the fractions from rats treated with vehicle and $0.08 \mu \mathrm{M}$ in fractions from rats treated with haloperidol. On the contrary, the results in Table 2 demonstrate that no differences were found in the response of adenylate cyclase to GTP in striatal fractions from animals treated with vehicle or haloperidol. The response to GTP was biphasic and a maximal response occurred at $1 \mu \mathrm{M}$ GTP, as shown previously (Treisman et al., 1983).

Activation of adenylate cyclase by calmodulin, GTP and GppNHp in animals treated chronically with haloperidol or vehicle and not withdrawn from the drugs before sacrifice

In order to assess whether the increased response to calmodulin and GppNHp in membranes from the striatum of rats withdrawn from treatment with haloperidol, as opposed to vehicle, was due to a compensatory response to continued receptor blockade, the activation of adenylate cyclase by calmodulin and by guanyl nucleotides in striata from rats not withdrawn from the drugs was examined. Male, Sprague-Dawley rats were treated for 14 days with haloperidol or vehicle as described in Methods but were sacrificed $1 \mathrm{hr}$ after the last injection. As shown in Fig. 3, the activity of adenylate cyclase in particulate fractions from the striatum of animals chronically treated with haloperidol was not significantly

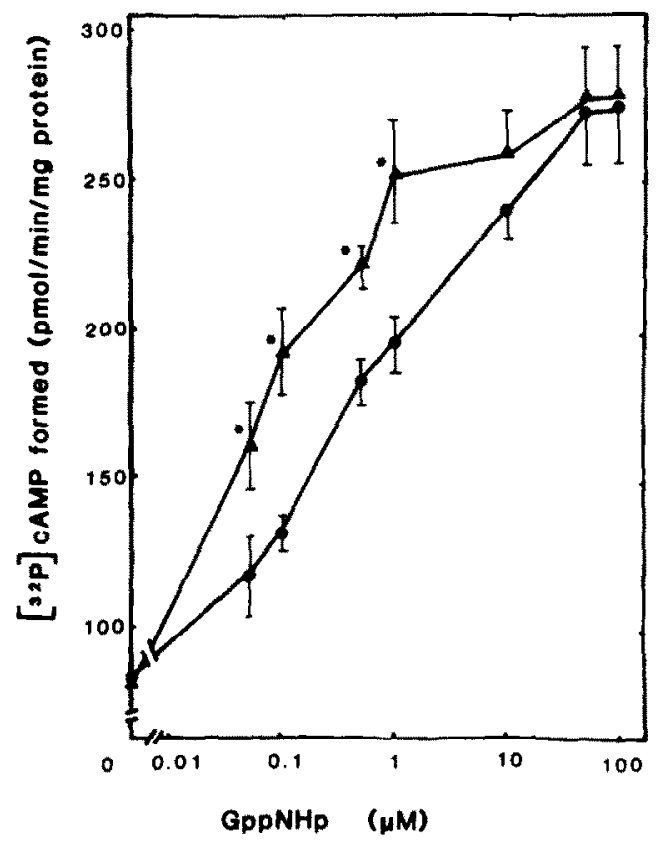

Fig, 2. Activation of the activity of adenylate cyclase by GppNHp in particulate fractions from the striatum of rats chronically treated with haloperidol $(\boldsymbol{A})$ or vehicle $(\boldsymbol{O})$ and withdrawn for 4 days. The activity of adenylate cyclase was measured in EGTA-washed striatal particulate fractions as described in Methods. Each point represents the average value from five different animals $\pm S E M .{ }^{*} P \leq 0.05$. 
Table 2. Activation of adenylate cyclase by GTP in particulate fractions from the striatum of animals chronically treated with haloperidol or vehicle and withdrawn for 4 days

\begin{tabular}{ccc}
\hline & \multicolumn{2}{c}{ Adenylate cyclase activity } \\
\cline { 2 - 3 } $\begin{array}{c}\text { GTP } \\
\text { concentration } \\
(\mu \mathrm{M})\end{array}$ & $\begin{array}{c}\text { Vehicle } \\
\text { (pmol/min }\end{array}$ & $\begin{array}{c}\text { Haloperidol* } \\
\text { mg protein) }\end{array}$ \\
\hline None & $83 \pm 3$ & $75 \pm 3$ \\
0.1 & $123 \pm 7$ & $116 \pm 8$ \\
1.0 & $179 \pm 9$ & $176 \pm 10$ \\
10.0 & $156 \pm 9$ & $158 \pm 9$ \\
100.0 & $158 \pm 23$ & $151 \pm 14$ \\
\hline
\end{tabular}

*Rats were treated with haloperidol or vehicle as described in Table 1. Results are given $\pm \mathrm{SEM}$ for $N=5$.

different from controls. The overall activity of adenylate cyclase was slightly but not significantly decreased in the particulate fractions from rats treated, but not withdrawn from, haloperidol as compared to controls. Although the absolute response values were slightly decreased with calmodulin, there was a 2-fold increase in sensitivity to calmodulin in the particulate fractions from rats treated with haloperidol as compared to controls. Apparent kinetic constants for the activation of adenylate cyclase by calmodulin in the two groups are given in Table 1. The change in sensitivity for calmodulin in the non-withdrawn animals was not statistically significant nor as great as for those

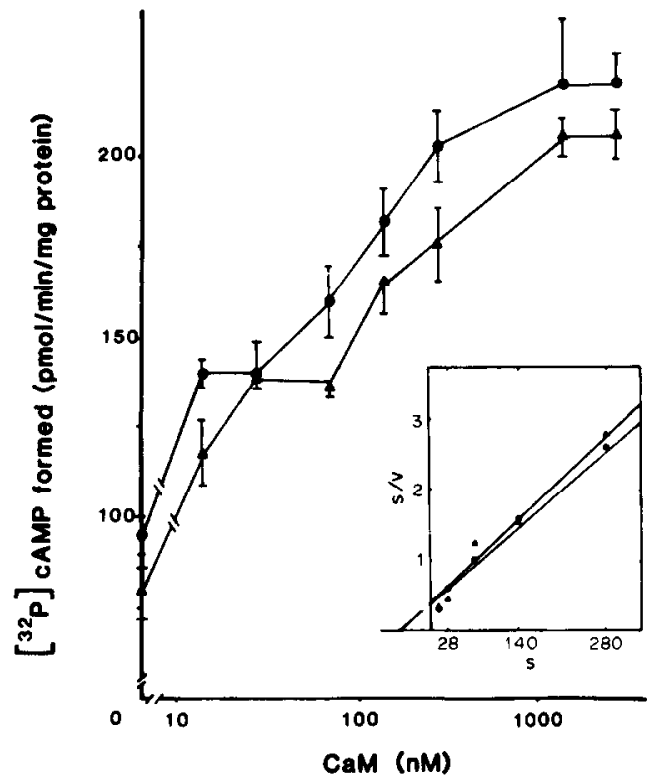

Fig. 3. Activation of the activity of adenylate cyclase by calmodulin $(\mathrm{CaM})$ in animals treated chronically with haloperidol $(\Delta)$ or vehicle $(\boldsymbol{O})$ and sacrificed $1 \mathrm{hr}$ after the last injection. The activity of adenylate cyclase was measured in EGTA-washed particulate fractions as described in Methods. Assays contained $0.12 \mu \mathrm{M}$ free $\mathrm{Ca}^{2+}(100 \mu \mathrm{M}$ added $\mathrm{CaCl}_{2}$ ). Each point represents the average value from five different animals \pm SEM. Inset: Results expressed as a Hanes plot with substrate (s) on the abscissa and substrate/velocity (s/v) on the ordinate. Kinetic constants from this form of analysis are shown in Table 1.
Table 3. Activation of adenylate cyclase by guanyl nucleotides and DA in striata from rats chronically treated with vehicle or haloperidol and sacrificed $1 \mathrm{hr}$ later

\begin{tabular}{lccc}
\hline & & \multicolumn{2}{c}{ Adenylate cyclase activity } \\
\cline { 3 - 4 } Addition & $\begin{array}{c}\text { Concentration } \\
\text { to assay }\end{array}$ & $\begin{array}{c}\text { Vehicle } \\
(\mu \mathrm{M})\end{array}$ & $\begin{array}{c}\text { Haloperidol* } \\
\text { (pmol/min }\end{array}$ \\
\hline None & & $95 \pm 5$ & $91 \pm 8$ \\
GppNHp & 0.1 & $128 \pm 12$ & $131 \pm 12$ \\
& 1.0 & $189 \pm 12$ & $196 \pm 12$ \\
& 10.0 & $267 \pm 6$ & $272 \pm 16$ \\
GTP & 100.0 & $311 \pm 11$ & $309 \pm 12$ \\
& 0.1 & $121 \pm 9$ & $131 \pm 12$ \\
DAt & 1.0 & $215 \pm 9$ & $207 \pm 13$ \\
& 1 & $27 \pm 2$ & $7 \pm 18$ \\
& 50 & $90 \pm 9$ & $108 \pm 9$
\end{tabular}

*Rats were treated for 14 days with vehicle or haloperidol as described in Methods and Table 1 and killed $1 \mathrm{hr}$ after the last injection. Adenylate cyclase activity was measured in EGTAwashed particulate fractions as described in Methods.

+ Results are given \pm SEM for $N=5$.

tAssays containing DA also contained $1 \mu \mathrm{M}$ GTP since GTP is required to detect activation by $D A$ in these washed fractions. Results are given as the pmol of cAMP/min per mg protein produced by DA above that produced by $1 \mu \mathrm{M}$ GTP.

$\S P \leq 0.05$ as compared to the value for vehicle-treated rats.

withdrawn from haloperidol. These results suggest that, in the same manner as the change in sensitivity to DA, the increased activation by calmodulin became more apparent after withdrawal of the drug.

Table 3 shows the data for activation of adenylate cyclase from the striatum by GTP, GppNHp and DA in fractions from the striatum of rats chronically treated with vehicle or halopcridol, but not withdrawn from the drugs before sacrifice. No significant differences in activation by GTP or GppNHp were found between the two groups. Activation of adenylate cyclase by a submaximal concentration of DA was decreased in striatal particulate fractions from rats treated with haloperidol as compared to controls, suggesting that haloperidol was still present in the membranes and blocking activation by DA.

Effect of haloperidol, administered acutely, on the activation of adenylate cyclase from the striatum of the rat by calmodulin

The effect of an acute treatment with haloperidol on the activity of adenylate cyclase and the activation by calmodulin was examined. The authors wished to determine further whether treatment with haloperidol directly affected the activation of adenylate cyclase by calmodulin. Rats were treated with either $0.6 \mathrm{mg} / \mathrm{kg}$ haloperidol subcutaneously or an cqual volume of vehicle and sacrificed $1.5 \mathrm{hr}$ later. The activation of adenylate cyclase by calmodulin and DA was determined in particulate fractions from the striatum of rats treated with haloperidol or vehicle. As shown in Table 4, there was no significant difference in the activity of adenylate cyclase between fractions from rats treated with haloperidol or vehicle. Similarly, the responsiveness to calmodulin in terms of percentage stimulation of basal activity was not significantly different between the two groups. The haloperidol present in the striatum after injection did block DA 
Table 4. Activation of adenylate cyclase by calmodulin (CaM) and DA in striata from rats treated acutely with haloperidol or vehicle

\begin{tabular}{|c|c|c|c|}
\hline \multirow[b]{2}{*}{$\begin{array}{l}\text { Addition } \\
\text { to assay }\end{array}$} & \multirow[b]{2}{*}{ Concentration } & \multicolumn{2}{|c|}{ Adenylate cyclase activity } \\
\hline & & $\begin{array}{l}\text { Vehicle } \\
\text { (pmol/min per }\end{array}$ & $\begin{array}{l}\text { Haloperidol* } \\
\text { mg protein) } \dagger\end{array}$ \\
\hline None & & $117 \pm 9$ & $114 \pm 13$ \\
\hline \multirow{4}{*}{$\mathrm{CaM}$} & $28 \mathrm{nM}$ & $158 \pm 14$ & $135 \pm 16$ \\
\hline & $140 \mathrm{nM}$ & $194 \pm 19$ & $167 \pm 14$ \\
\hline & $280 \mathrm{nM}$ & $215 \pm 23$ & $192 \pm 32$ \\
\hline & $1400 \mathrm{nM}$ & $226 \pm 30$ & $230 \pm 20$ \\
\hline \multirow[t]{2}{*}{ DA } & $1 \mu \mathrm{M}$ & $47 \pm 7$ & $8 \pm 8 \S$ \\
\hline & $50 \mu \mathrm{M}$ & $93 \pm 8$ & $118 \pm 11$ \\
\hline
\end{tabular}

-Male Sprague-Dawley rats were injected with either $0.6 \mathrm{mg} / \mathrm{kg}$ (s.c.) haloperidol or an equal volume of vehicle and sacrificed $1.5 \mathrm{~h}$ later. The activity of adenylate cyclase was measured in EGTAwashed striatal particulate fractions as described in Methods. Assays containing calmodulin (CaM) also contained $100 \mu \mathrm{M}$ $\mathrm{CaCl}_{2}\left(0.12 \mu \mathrm{M}\right.$ free $\left.\mathrm{Ca}^{2+}\right)$.

+ Results are given \pm standard error of the mean, $N=3$.

$\ddagger$ Dopamine (DA)-stimulated activity was determined as described in Table 1. Adenylate cyclase activity in the presence of $1 \mu \mathrm{M} \mathrm{GTP}$ was $285 \pm 30$ and $220 \pm 9 \mathrm{pmol} / \mathrm{min}$ per $\mathrm{mg}$ protein in particulate fractions from the striatum from vehicle and haloperidoltreated rats, respectively.

$\S P<0.01$ as compared to the value for vehicle-treated rats.

receptors as shown by the decrease in activation of adenylate cyclase by $1 \mu \mathrm{m} \mathrm{DA}$ in striata from rats treated with haloperidol as compared to controls (Table 4).

Haloperidol added to particulate fractions of striatum in vitro did not decrease the basal activity of adenylate cyclase until concentrations of $10 \mu \mathrm{M}$ were attained (data not shown). Similarly, halopcridol in vitro did not inhibit activation by calmodulin until concentrations of $10 \mu \mathrm{M}$ were reached, even when haloperidol was preincubated with the membranes for $5-10 \mathrm{~min}$ at $37^{\circ} \mathrm{C}$.

The activity of GTPase in particulate fractions from the striatum of rats treated chronically with haloperidol or vehicle

The results have shown that adenylate cyclase in particulate fractions from the striatum of rats withdrawn from chronic treatment with haloperidol had an increased sensitivity to GppNHp but not to GTP. An increase in the activity of GTPase in striatal particulate fractions from rats treated with haloperidol could negate possible increases in activation of GTP. The hydrolysis of $10^{-7} \mathrm{M}$ GTP was measured in particulate fractions from the striatum of animals treated with drug and control animals. This concentration was near the apparent $\mathrm{K}_{\mathrm{a}}$ for the low $\mathrm{K}_{\mathrm{m}}$ for GTPase related to adenylate cyclase in membranes (Cassel and Selinger, 1976; Koski and Klee, 1981). No change was found in activity of GTPase in particulate fractions from the striatum of rats treated with vehicle or haloperidol withdrawn from treatment 4 days, being $24.2 \pm 1.5$ and $23.7 \pm$ $1.5 \mathrm{pmol} / \mathrm{min}$ per $\mathrm{mg}$ protein, respectively. Similarly, there was no significant change in hydrolysis of $10^{-7} \mathrm{M}$ GTP in particulate fractions from the striatum of rats not withdrawn from vehicle and halo- peridol, being $24.3 \pm 1.7$ and $21.7 \pm 1.0 \mathrm{pmol} / \mathrm{min}$ per mg protein, respectively.

Activation of adenylate cyclase by dopamine in particulate fractions from the striatum of rats withdrawn from chronic treatment with vehicle or haloperidol

It has previously been demonstrated that activity of adenylate cyclase in particulate fractions from the striatum of rats chronically treated with haloperidol was 3-4-fold more sensitive to DA than that from controls (Gnegy et al., 1977b). To confirm that the animals used in the present studies were supersensitive to DA, the activation of adenylate cyclase by 1 and $50 \mu \mathrm{M}$ DA was examined in the striatum from drug-treated and control animals. The apparent $\mathrm{K}_{\mathrm{a}}$ of adenylate cyclase for DA in this particulate preparations was approx. $1 \mu \mathrm{M}$. Fifty micromoles of DA represents a maximal activating concentration (Gnegy and Treisman, 1981). The activation of adenylate cyclase by $1 \mu \mathrm{M}$ DA was significantly greater in particulate fractions from rats treated with haloperidol as compared to controls, being $40 \pm 6$ and $24 \pm 3 \mathrm{pmol} / \mathrm{min}$ per $\mathrm{mg}$ protein, respectively $(N=5$, $P<0.05$ for haloperidol-treated as compared to vehicle-treated fractions). The amount of cAMP produced by $50 \mu \mathrm{M}$ DA was the same in fractions from rats treated with vehicle and haloperidol, $93 \pm 7$ and $88 \pm 11 \mathrm{pmol} / \mathrm{min}$ per $\mathrm{mg}$ protein, respectively.

\section{DISCUSSION}

Rats withdrawn from chronic treatment with neuroleptic drugs, such as haloperidol, exhibit behavioral supersensitivity to DA agonists. Increased activity of DA receptors has been demonstrated neurochemically in the striatum of the rat by an increase in the binding of $\left[{ }^{3} \mathrm{H}\right]$ haloperidol (Burt et al., 1977) as well as an increase in the sensitivity of adenylate cyclase to DA (Gnegy et al., 1977a. b). The results of this study demonstrate that adenylate cyclase in the striatum developed a heightened sensitivity for agents acting beyond the receptor as a result of chronic treatment with antipsychotic drugs. Previous studies demonstrated that there was a 3-4-fold decrease in the apparent $\mathrm{K}_{\mathrm{a}}$ for activation by $\mathrm{DA}$ of adenylate cyclase in membranes from the striatum of rats treated chronically and withdrawn from haloperidol as compared to vehicle-treated controls (Gnegy et al., 1977a). A 5-fold increase in the sensitivity of adenylate cyclase in the striatum for calmodulin and a 6-fold increase in sensitivity for GppNHp in membranes from the striatum of rats chronically treated with haloperidol has now been demonstrated. This represents a large kinetic change as a result of chronic treatment with neuroleptics and would result in a large increase in the activation of adenylate cyclase by these agents in vivo.

Calmodulin has been shown to increase the sensitivity of adenylate cyclase in the striatum for DA and thus to play a role in regulating sensitivity to DA 
(Gnegy and Treisman, 1981). The exact mechanism by which calmodulin activates adenylate cyclase is not known. Studies have suggested that it acts directly at the catalytic subunit (Salter, Krinks, Klee and Neer, 1981) and does not require GTP for its activity (Heideman et al., 1982; Seamon and Daly, 1982). Calmodulin has been shown to increase the activation of adenylate cyclase by DA in the striatum (Gnegy and Treisman, 1981) and retina (Gnegy, Muirhead and Harrison, 1984) and $\beta$-adrenergic receptor activation of adenylate cyclase in the cerebellum (Malnoë, Stein, and Cox, 1983). Calmodulin can increase the sensitivity for guanyl nucleotides of the calmodulin-sensitive adenylate cyclase in the cerebral cortex (Brostrom et al., 1978). It is possible that calmodulin could act at the catalytic subunit in such a manner as to increase the association between the guanyl nucleotide binding protein and the catalytic subunit.

Activation of adenylate cyclase by hormones is mediated by a GTP-binding protein termed $\mathrm{N}_{\mathrm{s}}$ consisting of $\alpha, \beta$ and $\gamma$ subunits. Guanyl nucleotides bind to the $\alpha$ subunit of $N_{s}$, which is a 45,000 dalton protein that mediates the activation of adenylate cyclase (Manning and Gilman, 1983). An increase in sensitivity of adenylate cyclase to GppNHp suggests that there could be a change in affinity of $\mathbf{N}_{\mathrm{s} z}$ for guanyl nucleotides or a higher affinity for coupling of $\mathbf{N}_{\mathrm{s} x}$ with the catalytic subunit as a consequence of supersensitivity. A decrease in coupling of receptoradenylate cyclase systems through the guanyl nucleotide binding protein has been reported to result from ligand-mediated desensitization in cell lines (Harden, Su and Perkins, 1979). Receptor-coupled inhibition of the activity of adenylate cyclase is mediated by another GTP-binding protein, $\mathbf{N}_{\mathrm{i}}$, that also consists of $\alpha, \beta$ and $\gamma$ subunits (Murayama and $\mathrm{Ui}, 1983$; Hildebrandt, Sekura, Codina, Iyengar, Manclark and Birnbaumer, 1983). Activation of DA D-2 receptors has been shown to be mediated through $\mathrm{N}_{\mathrm{i}}$ and results in attenuation of adenylate cyclase activity in the pituitary gland (Cote, Grewe and Kebabian, 1981) and striatum (Stoof and Kebabian, 1981). Although the present studies have been directed toward investigating the activation of adenylate cyclase by DA (D-1 receptor activity) through $\mathrm{N}_{\mathrm{s}}$, the increased GppNHp activation could represent a decrease in $\mathrm{N}_{\mathrm{i}}$ activity.

However, chronic treatment with haloperidol did not alter the response of adenylate cyclase in the striatum to GTP. The lack of change in stimulation by GTP could not be attributed to a significant alteration in GTPase activity in the membranes from the striatum of rats treated with haloperidol. Previous work suggests that GTP, in the absence of DA, is activating a separate component of adenylate cyclase from that of small concentrations of GppNHp (Treisman et al., 1983). A kinetic analysis of the data demonstrated two components of the activity of adenylate cyclase in the striatum of the rat. One component was activated by calmodulin and concentrations of GppNHp below $1 \mu \mathrm{M}$. The other component was activated by GTP and larger concentrations of GppNHp. The results attained in this study suggest that chronic treatment with haloperidol induces an alteration in the calmodulin-sensitive component of adenylate cyclase which may be independent of the GTP-activated component. It has similarly been demonstrated that when the sensitivity of adenylate cyclase to DA in retina is modified by light, then the sensitivity of the enzyne to calmodulin and GppNHp, but not to GTP, is altered (Gnegy et al., 1984).

The increase in sensitivity to calmodulin and GppNHp is most likely to be a compensatory supersensitivity resulting from chronic receptor blockade. There was no change in stimulation by GppNHp or GTP and no significant change in activation by calmodulin in particulate fractions from the striatum of rats treated with haloperidol and not withdrawn from the drug, as compared to control. The increase in sensitivity to calmodulin could develop during chronic treatment with drugs but is most apparent when the drug is withdrawn. The reason that the sensitivity to GppNHp and calmodulin did not change prior to withdrawal is not clear. It is possible that the interaction between the dopamine receptor and $\mathrm{N}_{\mathrm{s}}$ is altered during chronic blockade, and it is only after withdrawal that the increased sensitivity of adenylate cyclase to actions mediated by $\mathrm{N}_{\mathrm{s}}$ or calmodulin are seen. The changes in sensitivity to calmodulin parallel the response of adenylate cyclase to DA. Results from the present studies, using acute treatment with haloperidol or in vitro addition to striatal membranes demonstrated that haloperidol did not directly inhibit activation of adenylate cyclase by calmodulin. Antipsychotic drugs, such as trifluoperazine, have becn shown to bind to calmodulin and prevent it from activating target enzymes (Levin and Weiss, 1977). Haloperidol is much weaker in its binding to calmodulin than trifluoperazine and might not be expected to inhibit the activity of calmodulin by directly inhibiting activation of adenylate cyclase at smaller concentrations (Weiss, Prozialeck, Cimino, Barnette and Wallace, 1980). The present results suggest that the increased responsiveness to calmodulin after withdrawal from chronic treatment with haloperidol is a consequence of chronic blockade of DA receptors as opposed to a release from continued direct inhibition of calmodulin.

In conclusion, the sensitivity of adenylate cyclase from the striatum of the rat to stimulation by calmodulin and GppNHp was increased after withdrawal from chronic treatment with haloperidol suggesting an increase in the coupling of DA receptors to adenylate cyclase. The supersensitivity, developed to these agents, may be a compensatory response to continued receptor blockade since the increased response was not detected in rats treated acutely with 
the drug. The increase in sensitivity to calmodulin and GppNHp correlated with an increase in sensitivity of adenylate cyclase to DA and appears to reflect an increase in the calmodulin-sensitive component of adenylate cyclase. These results demonstrate that neurochemical changes occurring as a result of chronic blockade of DA receptors can develop at a level beyond that of the receptor itself and can be reflected in the coupling mechanism of the receptor as well as at the receptor itself.

Acknowledgements - The technical help of Lynn Iwaniec and Sheila McDonnell is gratefully acknowledged. The authors would like to thank Linda Harbison for her help and expertise in preparation of this manuscript.

\section{REFERENCES}

Brostrom C. O., Brostrom M. A. and Wolff, D. J. (1977) Calcium-dependent adenylate cyclase from rat cerebral cortex. Reversible activation by sodium fluoride. J. biol. Chem. 242. 5677-5685.

Brostrom M. A., Brostrom C. O. and Wolff D. J. (1978) Calcium-dependent adenylate cyclase from rat cerebral cortex: activation by guanine nucleotides. Archs Biochem. Biophys. 191, 341-350.

Burt D. R., Creese I. and Snyder S. H. (1977) Antischizophrenic drugs: chronic treatment elevates dopamine receptor binding in brain. Science 196, 326-328.

Cassel D. and Selinger Z. (1976) Catecholamine-stimulated GTPase activity in turkey erythrocte membranes. Biochim. biophys. Acta 452, 538-551.

Cassel D., Levkovitz H. and Selinger Z. (1977) The regulatory GTPase cycle of turkey erythrocyte adenylate cyclase. J. Cyclic Nucleotide Res. 3, 393-406.

Cheung W. Y., Bradham L. S., Lynch T. J., Lin Y. M. and Tallant E. A. (1975) Protein activator of cyclic $3^{\prime}: 5^{\prime}$-nucleotide phosphodiesterase of bovine or rat brain also activates its adenylate cyclase. Biochem. biophys. Res. Commun. 66, 1055-1062.

Christensen A. V., Fjalland B. and Møller Nielsen I. (1976) On the supersensitivity of dopamine receptors, induced by neuroleptics. Psychopharmacology 48, 1-6.

Cote T. E., Grewe C. N. and Kebabian J. W. (1981) Stimulation of a D-2 dopamine receptor in the intermediate lobe of the rat pituitary gland decreases the responsiveness of the $\beta$-adrenoceptor: biochemical mechanism. Endocrinology 108, 420-426.

Dedman J. R., Potter J. D. and Means A. R. (1977) Biological cross-rcactivity of rat testis phosphodiesterase activator protein and rabbit skeletal muscle troponin-C. J. biol. Chem. 252, 2437-2440.

Gnegy M. and Treisman G. (1981) Effect of calmodulin on dopamine sensitive adenylate cyclase activity in rat striatal membranes. Molec. Pharmac. 19, 256-263.

Gnegy M. E., Lucchelli A. and Costa E. (1977a) Correlation between drug-induced supersensitivity of dopamine dependent striatal mechanisms and the increase in striatal content of the $\mathrm{Ca}^{2+}$ regulated protein activator of cAMP phosphodicsterasc. Naunyn-Schmiedebergs Arch. pharmac. 301, 121-127.

Gnegy M., Uzunov P. and Costa E. (1977b) Participation of an endogenous $\mathrm{Ca}^{2+}$-binding protein activator in the development of drug-induced supersensitivity of striatal dopamine receptors. J. Pharmac. exp. Ther. 202, 558-564.

Gnegy M. E., Nathanson J. A. and Uzunov P. (1977c) Release of phosphodiesterase activator by cyclic AMPdependent ATP: protein phosphotransferase from subcellular fractions of rat brain. Biochim. biophys. Acta 497 , 75-85.
Gnegy M. E., Lau Y. S. and Treisman G. (1980) Role of calmodulin states of altered catecholamine sensitivity. Ann. N. Y. Acad. Sci. 356, 304-318

Gnegy M. E., Muirhead N. and Harrison J. K. (1984) Regulation of calmodulin- and dopamine-stimulated adenylate cyclase activities by light in bovine retina. $J$. Neurochem. 42, 1631-1640.

Gopalakrishna R. and Anderson W. B. (1982) $\mathrm{Ca}^{2+}$-induced hydrophobic site on calmodulin: application for purification of calmodulin by phenyl-sepharose affinity chromatography. Biochem. biophys. Res. Commun. 104, 830-836.

Hanhauer I, Pradham S. and Yang H.-Y. T. (1980) Role of calmodulin in dopaminergic transmission. Ann. N.Y. Acad. Sci. 356, 292-303.

Harden T. K., Su Y-F. and Perkins J. P. (1979) Catecholamine-induced desensitization involves an uncoupling of $\beta$-adrenergic receptors and adenylate cyclase. J. Cyclic Nucleotide Res. 5, 99-106.

Heideman W., Wierman B. M. and Siorm D. R. (1982) GTP is not required for calmodulin stimulation of bovine brain adenylate cyclase. Proc. natn. Acad. Sci. U.S.A. 79, $1462-1465$.

Hildebrandt J. D., Sekura R. D., Codina J., Iyengar R., Manclark C. R. and Birnbaumer L. (1983) Stimulation and inhibition of adenylate cyclases mediated by distinct regulatory proteins. Nature $\mathbf{3 0 2}$, 706-709.

Hornykiewicz O. (1973) Parkinson's disease: from brain homogenate to treatment. Fedn Proc. Fedn Am. Socs exp. Biol. 32, 183-190.

Hornykiewicz O. (1975) Parkinsonism induced by dopaminergic antagonists. Adv. Neurol. 9, 155-164.

Iwatsubo K. and Clouet D. H. (1975) Dopamine-sensitive adenylate cyclase of the caudate nucleus of rats treated with morphine or haloperidol. Biochem. Pharmac. 24, 1499-1503.

Klawans H. L. and Rubovits R. (1972) An experimental model of tardive dyskinesia. J. neurol. Trans. 33, 235-246.

Klee C. B. and Krinks M. (1978) Purification of cyclic $3^{\prime} 5^{\prime}$-nucleotide phosphodiesterase inhibitory protein by affinity chromatography on activator protein coupled to Sepharose. Biochemistry 10, 120-126.

Koski G. and Klee W. A. (1981) Opiates inhibit adenylate cyclase by stimulating GTP hydrolysis. Proc. natn. Acad. Sci. U.S.A. 78, 4185-4189.

Krishna G., Weiss B. and Brodie B. B. (1968) A simple sensitive method for the assay of adenyl cyclase. $J$. Pharmac. exp. Ther. 163, 379-385.

Levin R. M. and Weiss B. (1977) Binding of trifluoperazine to the calcium-dependent activator of cyclic nucleotide phosphodiesterase. Molec. Pharmac. 13, 690-697.

Limbird L. E. (1981) Activation and attenuation of adenylate cyclase: the rolc of GTP-binding protcins as macromolecular messengers in receptor-cyclase coupling. Biochem. J. 195, 1-13.

Lowry O. H., Rosebrough N. J., Farr A. L. and Randall R. J. (1951) Protein measurement with the Folin phenol reagent. J. biol. Chem. 193, 265-275.

Malnoë A., Stein E. A. and Cox J. A. (1983) Synergistic activation of bovine cerebellum adenylate cyclase by calmodulin and $\beta$-adrenergic agonists. Neurochem. Int. 5, 65-72.

Manning D. R. and Gilman A. G. (1983) The regulatory components of adenylate cyclase and transducin: A family of structurally homologous guanine nucleotide binding proteins. J. biol. Chem. 258, 7059-7063.

Marshall A. M. and Mishra R. K. (1980) Dopaminesensitive adenylate cyclase and dopamine/neuroleptic receptor binding: Effect of neuroleptic drugs. $A d v$. Biochem. Psychopharmac. 24, 153-157.

Murayama T. and Ui T. (1983) Loss of the inhibitory function of the guanine nucleotide regulatory component of adenylate cyclase duc to its ADP ribosylation by 
islet-activating protein, pertussis toxin, in adipocyte membranes. $J$. biol. Chem. 258, 3319-3326.

Nanninga B. and Kempen R. (197.1) Role of magnesium and calcium in the first and second contraction of glycerinextracted muscle fibers. Biochemistry 10, 2449-2456.

Rodbell M. (1980) The role of hormone receptors and GTP-regulatory proteins in membrane transduction. Nature 284, 17-22.

Salter R. S., Krinks M. H., Klee C. B. and Neer E. J. (1981) Calmodulin activitates the isolated catalytic unit of brain adenylate cyclase. J. biol. Chem. 256, 9830-9833.

Sayers A. C., Bürki H. R., Ruch W. and Asper H. (1975) Neuroleptic-induced hypersensitivity of striatal dopaminc receptors in the rat as a model of tardive dyskinesias. Effect of clozapine, haloperidol, loxapine and chlorpromazine. Psychopharmacology 41, 97-104.

Seamon K. B. and Daly J. W. (1982) Calmodulin stimu- lation of adenylate cyclase in rat brain membranes does not require GTP. Life Sci. 30, 1457-1466.

Stoof J. C. and Kebabian J. W. (1981) Opposing roles for D- 1 and D-2 dopamine receptors in efflux of cyclic AMP from rat neostriatum. Nature 294, 366-368.

Tarsy D. and Baldessarini R. J. (1974) Behavioral supersensitivity to apomorphine following chronic treatment with drugs which interfere with the synaptic function of catecholamines. Neuropharmacology 13, 927-940.

Treisman G. J., Bagley S. and Gnegy M. E. (1983) Calmodulin-sensitive and calmodulin-insensitive components of adenylate cyclase activity in rat striatum have differential responsivencss to guanyl nucleotides. J. Neurochem. 41, 1398-1406.

Weiss B., Prozialeck W., Cimino M., Barnette M. S. and Wallace T. L. (1980) Pharmacological regulation of calmodulin. Ann. N.Y. Acad. Sci. 356, 319-345. 